\title{
Clergy (Kler) by Wojciech Smarzowski - The Image of Catholic Priests in Polish Movies After 1989
}

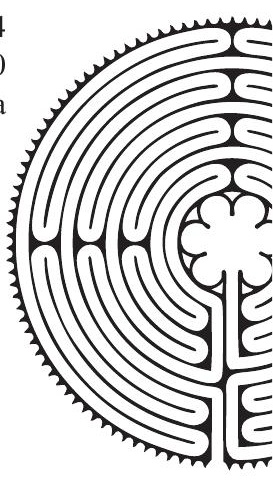

\author{
Piotr Zwierzchowski iD https://orcid.org/0000-0002-1770-777X \\ Kazimierz Wielki University \\ piotr.zwierzchowski@ukw.edu.pl
}

\begin{abstract}
Clergy (Kler, 2018) by Wojciech Smarzowski has aroused great controversy and many discussions about the position and role of the Catholic Church in contemporary Poland. I would like to look at the portraits of priests in the film in relation to the images previously created in Polish cinema. I am not going to analyze particular examples, but point to selected motifs and characters in order to interpret the images of clergymen and the church in their context. I will consider both the construction of individual characters and the image of the Catholic Church as an institution.
\end{abstract}

Keywords: Polish cinema, images of Catholic priests, Clergy, Wojciech Smarzowski

Słowa kluczowe: kino polskie, obrazy katolickiego kleru, Kler, Wojciech Smarzowski

1.

The political shift taking place in Poland in the late 1980s and early 1990s freed religious themes, in the broad sense of the term, from institutional censorship. Polish cinema, too, was free to address such topics to a much greater extent than before. Still, as Krzysztof Kornacki wrote,

The image of Catholicism in post-1989 cinema is somewhat lopsided; its institutional dimension (priests, saints, churches, believers as a background) and stereotypical patterns dominate. ${ }^{1}$

${ }^{1}$ KK [Krzysztof Kornacki], Religii przedstawienie w kinie polskim, [in:] Światowa encyklopedia filmu religijnego, Fr. M. Lis, A. Garbicz (eds.), Kraków 2007, p. 460. All quotes translated by Marcin Turski. 
The figures of Catholic priests did indeed appear in films quite often, which was obviously due to the presence and significance of the Catholic Church in Polish history, culture, society, and everyday life. However, their representations in film are relatively undifferentiated. Historical and hagiographic narratives dominate, as do images of authorities and leaders. There are also quite a few portraits of doubting priests, yet their dilemmas are mostly connected with the necessity to cope with their own weaknesses and with their priesthood, and to a lesser extent with problems of faith.

The least numerous group includes priests that exert a negative influence on society. Such films have been released only in recent years; earlier criticism of the clergy had been rather gentle, often camouflaged by comic elements. None of these films have aroused such interest and emotions as Clergy (2018) by Wojciech Smarzowski, a critique on the attitudes, conduct and values of Catholic priests and the church as an institution. The movie attracted over 5 million viewers in cinemas alone, not counting distribution on discs, streaming platforms, and television; this is by far the best box office figure for Polish films in the twentieth century, and the third best result after 1989. The movie, moreover, triggered numerous discussions and disputes, and became the subject of debates, polemics, and reviews, often stirring up strong emotions.

Clergy was unprecedented in Polish cinema, which does not mean it was made in a vacuum. I do not want to recount the discussions about the position and role of the Catholic Church in contemporary Poland, nor make a detailed analysis of the various aspects of the film itself. My aim is to look at the portrayal of the priest-protagonists in the context of earlier images of the clergy in Polish cinema. ${ }^{2}$ Referring to their different types and functions, I would like to analyse in what ways Smarzowski's characters stand out. I will not elaborate on individual examples, trying above all to create a kind of map of topoi, motifs, and figures to interpret in this context the image of priests and the church in Clergy.

\section{2.}

\section{Historical and hagiographic narratives ${ }^{3}$}

After 1989, both to take up a previously forbidden topic and to fill gaps in the most recent history, Polish movies started to portray priests who confronted the communist regime. According to Robert Birkholc, they were thus "hostages of history, serving both God and fatherland."” These films show the image of an invincible priest,

\footnotetext{
${ }^{2}$ At this point, I must make a few important caveats. First, my focus is on the feature film. Second, I disregard any motifs related to religiosity or spirituality, and only consider the image of Roman Catholic clergy. Finally, I assume that the image of monks and nuns, if only because of their social roles, is different.

${ }^{3}$ I owe the term to the text by Robert Birkholc, Duszpasterze, kapłani i klechy... Księża w polskim filmie fabularnym, "Magazyn Filmowy" 2018, no. 10, p. 31.

${ }^{4}$ Ibidem, p. 30.
} 
standing firm by patriotic values, whose faith allows him to persevere even in the face of persecution and imminent risk of losing his life. Any doubts, any possible imperfections of the priest's image, only serve to make him more human and are not discursive in nature. The most notable examples include Prymas. Trzy lata $z$ tysiaca (The Primate: Three Years Out of a Thousand, 2000) by Teresa Kotlarczyk, about the incarceration of Primate of Poland Cardinal Stefan Wyszyński in 1953, and Popiełuszko. Wolność jest w nas (Popiełuszko: Freedom is Within Us, 2009) by Rafał Wieczyński, dedicated to Fr. Jerzy Popiełuszko, murdered in 1984 by Secret Service officers. $^{5}$

Clergymen portrayed "through the prism of national and patriotic values" are also depicted in films that attempt to create patriotic family sagas, such as Panny $i$ wdowy (Maidens and Widows, 1991) by Janusz Zaorski; Kuchnia polska (Polish Cuisine, 1991) by Jacek Bromski; Śmierć jak kromka chleba (Death Like a Slice of Bread, 1994) by Kazimierz Kutz, which reconstructed the massacre in the Wujek coal mine in the first days under the imposition of martial law in Poland; and the melodramatic Pokuszenie (Temptation, 1995) by Barbara Sass. ${ }^{6}$ A charming and humorous image of clergy involved in the struggle against the communist regime is offered in Waldemar Krzystek's 80 milionów (80 Million, 2011).

Interestingly, missing from the historical and hagiographic depictions is Karol Wojtyła, later Pope John Paul II. While John Paul II has become a protagonist of dozens of documentaries, he is featured as a cinematic figure in only two teleplays by Television Theatre (Teatr Telewizji). Poles were merely coproducers of the oftquoted biopics of Wojtyła: Pope John Paul II (2005) by John Kent Harrison, and first and foremost Giacomo Battiato's Karol. Un uomo diventato papa (2005) and Karol. Un papa rimasto uomo (2005).

Fr. Marek Lis observed that out of the various films shot all over the world, possibly only the creators of the second part of Karol managed to avoid "the unbearable superficiality of film characters, balancing between trivial anecdotes and hagiographic tendencies in the depiction of heroic figures." Although one can argue with the assessment of the film itself, Lis has aptly characterized the underlying ideological, scriptural, and staging problems regarding the figure of Karol Wojtyła. In Polish cinema, this was compounded by the position and perception of John Paul II in domestic culture, where any potential cinematic biography, regardless of its depiction, would likely have evoked disappointment or controversy. No wonder, then, that Polish cinema preferred to play it safe.

${ }^{5}$ Another interpretation of the movie was offered by Daria Mazur, for whom the film indicated the major role of religious experience as the foundation of individual faith. D. Mazur, Prymat doświadczenia religijnego nad instytucjonalnościa. Obraz duchowieństwa w filmach "Faustyna" Jerzego Lukaszewicza $i$ "Prymas. Trzy lata z tysiaca" Teresy Kotlarczyk, [in:] Kino polskie po roku 1989, P. Zwierzchowski, D. Mazur (eds.), Bydgoszcz 2007, p. 48.

${ }^{6}$ Ibidem, p. 49. The protagonist of the last movie was alleged to exhibit features of Cardinal Primate Wyszyński, and therefore later the film was referred to after Teresa Kotlarczyk's one.

${ }^{7}$ Fr. M. Lis, Filmowe portrety Karola Wojtyly. Rekonesans, [in:] Filmowa biografistyka. Ekranowe interpretacje losów i faktów, T. Szczepański, S. Kołos (eds.), Toruń 2007, p. 82. See also A. Garbicz, Fr. M. Lis, Filmowe portrety pontyfikatu. Jan Pawet II w 100 odstonach, Katowice 2007. 


\section{Authority and leadership}

Both Wyszyński and Popiełuszko are depicted as flawless authority figures. Furthermore, no one doubts that they were spiritual directors and leaders of Poles. However, in this category I wish to draw attention to another character type. I refer here to fictional heroes who are certainly less ideal and have numerous minor weaknesses, but are unquestionable leaders of the local community, providing support and assistance to individuals. In some films and TV series their social position is depicted sympathetically, and at other times with gentle irony, but rarely with scathing criticism. Interestingly, this image occurs mainly in comedies and soap operas.

Pastor Antoni Wójtowicz (Włodzimierz Matuszak), the protagonist of the series Plebania (Parsonage, 2000-2012) was no doubt such a priest. Patient, calm, always ready to help, he is an unquestioned authority and a pillar of support for the local community. The very high viewing figures of the series, sometimes exceeding 7 million, were to a large extent attributable to this image, which also contributed to the creation of the image of the priest in popular culture. ${ }^{8}$ Priests who are authorities for their parishioners include the eponymous protagonist of the 300-plus episodes of the crime series Ojciec Mateusz (Father Mateusz, 2008-2020; the Polish version starring Artur Żmijewski of the Italian Don Matteo), and Piotr Kozioł from the series Ranczo (Ranch, 2006-2016) by Wojciech Adamczyk, viewed by an audience of 10 million.

The protagonist of Jacek Bromski's comedies U Pana Boga za piecem (God's Little Stove, 1998), U Pana Boga w ogródku (God's Little Garden, 2007; series 2007-2009) and U Pana Boga za miedza (God's Little Field, 2009) is Father Antoni, a parish priest in eastern Poland. He seems clumsy at times, detached from the world, living at his own pace, bowing to no one, conversing with the Holy Virgin much in the manner of Tevye the Dairyman, and interpreting the tenets of the faith in the spirit of folk piety and life pragmatism. Without a doubt, however, he is, albeit informally, the most important person in town. Everyone heeds his advice and instructions, including the town authorities and the police; no important decision is made without him and he protects his flock from strangers.

Wójtowicz, Kozioł and Antoni are plebeian priests, born in rural areas, close to the faithful and familiar with their mentality, seemingly modern, but in fact quite conservative; they are cut off from politics, yet they wield considerable influence over the local authorities. It is hardly a coincidence that all these films and TV series are set in eastern Poland, where the society is much more conservative and the position of the Catholic Church is much firmer. It should also be noted that the religiosity and confidence in priests as well as their closeness to the faithful is higher in the rural areas than in big cities, which is also reflected in the film images of the Polish clergy. ${ }^{9}$ It is no accident that "while in Polish cinema the higher dignitaries of the church are

${ }^{8}$ Significantly, not all priests in the series are unambiguously positive characters, but the figure of the parish priest is so dominant that he seems to offset the others. See B. Laciak, Kwestie spoteczne w polskich serialach obyczajowych - prezentacje i odbiór, Warszawa 2013, pp. 78-89.

${ }^{9}$ Fr. A. Draguła, Księża prowincjonalni. Obraz kapłana $w$ twórczości teatralnej $i$ filmowej Przemysława Wojcieszka, "Notatnik Teatralny" 2008, no. 48, pp. 141-146. 
usually hieratic and grandiose, the clergy from the provinces are homey, direct and jovial." 10

Good priests help people through life's problems; they are role models and signposts, but this need not often be due to their theological standing. In popular films and TV series the problem of a priest's identity and his bond with God is practically absent. "The spirituality of the priest on screen is non-existent. And yet the true priesthood emanates to the people around. On television, a priest is only supposed to fulfil his social obligations," said Father Kazimierz Orzechowski, himself an actorpriest who has repeatedly been cast as a clergyman, such as in the popular series Złotopolscy (The Zlotopolskis). ${ }^{11}$

\section{A doubting priest}

The two dominant images of the steadfast patriot priest and the good-natured provincial pastor endowed with authority and/or informal power, along with such motifs as the confrontation of the Christian message with reality, the crisis of faith, and finally the criticism of religious institutions, disappeared. Less frequently addressed was the problem of the priest's struggling with his vocation or even with God, or the existential drama of a man, enhanced by his membership in the clerical state. Referring to the existential narrative in films about priests, Robert Birkholc singled out such contemporary movies as Cudowne miejsce (A Miraculous Place, 1994) by Jan Jakub Kolski, Historie miłosne (Love Stories, 1997) by Jerzy Stuhr, and $W$ imie... (In the Name of..., 2013) by Małgorzata Szumowska.

Cudowne miejsce can be seen as a profound story about a priest's coming to terms with his vocation, about divergent interpretations of this vocation and a study of the priest figure, with his fair share of weaknesses such as pride and succumbing to the temptations of everyday life. ${ }^{12}$ Daria Mazur, however, writes:

The test of the priest's stance is enveloped in Jan Jakub Kolski's signature aura of pagan magic and apocalyptic exuberance; as a result, the story transcends the framework imposed by Roman Catholic doctrine and the conflict appears artificial. ${ }^{13}$

An internal struggle of another kind is experienced by the protagonist of Historie mitosne, a priest who suddenly learns that he has an eleven-year-old daughter. Her entry into his life makes him acutely aware that although he has preached about love before, he had little clue what it means. The tenets of faith and moral principles become more important to him than the rules of conduct in the institutional church. Therefore, he leaves the church to take care of his daughter, treating it as the fulfilment of Christian love for God.

\footnotetext{
${ }^{10}$ Robert Birkholc, op. cit., p. 31.

${ }^{11}$ T. Ponikło, Kuszace sutanny. Wizerunek księdza w serialach, "Tygodnik Powszechny" 2008, no. 45 , p. 18.

${ }^{12}$ See Fr. A. Luter, Ksiadz w polskim filmie, [in:] Ukryta religijność kina, Fr. M. Lis (ed.), Opole 2002, p. 45.

${ }^{13}$ D. Mazur, op. cit., p. 51.
} 
Dilemmas concerning carnality and desire are rarely experienced by the priests depicted in Polish movies. A notable exception in this respect is Szumowska's $W$ imię... Even if certain situations are overdrawn it is worth noting - following Robert Birkholc - that it is the first film to show priests as flesh and blood, carnal people. In earlier films, even if priests experienced carnal desires, "their dilemmas were presented as moral or existential abstractions." ${ }^{14} \mathrm{~W}$ imię... triggered much discussion, although it will remain "for most viewers a sleekly packaged, safe phantasy about the dilemmas of a priest and Catholic hypocrisy." 15

Most films on the topic feature liturgy, prayer, symbols, and religious doctrine, yet theological reflection is rare in Polish cinema, especially in the character of the priest. This in fact seems to be a part of a broader phenomenon, applying not only to movies. Polish Catholicism is popular rather than intellectual, and this translates into the dilemmas and crises of the priests depicted in films. It is hard to find priests who would argue with God. Rather, they wrestle with their own weaknesses such as loneliness, sexual orientation, alcohol, and the inability to love another human being. Most of these movies do not really depict priests as such, as observed by Fr. Adam Boniecki, who commented on Kto nigdy nie żyt... (Who Has Never Lived..., 2006) by Andrzej Seweryn (a young priest caring for drug addicts experiences a crisis of faith when it turns out that he himself is HIV positive), but rather as people in extreme situations. ${ }^{16}$

\section{Negative social impact}

In Polish movies released before 1989 the priest was quite often a symbol of backwardness and negative conservatism; upon the political and economic transformation of the late 1980s and early 1990s, such portrayals became far less frequent. In a sense, Polish cinema continued to pay a debt to the church for the role it played during the long period of communist rule. ${ }^{17}$ Furthermore, the social position and political impact of the church were substantial enough to discourage addressing critical topics, and besides, audiences were not ready for that. Importantly, this subject matter was addressed by artists favourably disposed towards the church. Thus, the first two decades of the new political landscape were dominated by historical, hagiographic, existential, and pop-cultural narratives. It was only changes in Polish society, the decreasing participation of Poles in religious practices and the growing aversion to the church while remaining people of faith, as well as the exposure in the media of sexual and financial scandals involving Catholic priests, that triggered "an intensification of the recent critical current, pointing out the irregularities within the Church." 18 Robert Birkholc mentions here movies such as Pokłosie (Aftermath, 2012) by Władysław Pasikowski, Pokot (Spoor, 2017) by Agnieszka Holland, and Clergy.

\footnotetext{
${ }^{14}$ R. Birkholc, op. cit., p. 34.

15 A. Piotrowska, Fantazja o fajnym księdzu, "Tygodnik Powszechny" 2013, no. 37, p. 40.

16 Fr. A. Boniecki, Sami, ale nie samotni, "Tygodnik Powszechny" 2006, no. 39, p. 18.

${ }_{17}$ M. Podsiadło, Wiek klęski. Kino Wojciecha Smarzowskiego, "Ekrany” 2016, no. 6, p. 51.

${ }^{18}$ R. Birkholc, op. cit., p. 31.
} 
Pasikowski and Holland depict priests whose views and lack of empathy towards other people and animals have a detrimental impact on the local community. In Pokłosie an anti-Semitic priest replaces one who is sensitive to human suffering. Pasikowski seems to be saying that this succession is not accidental, as this is the direction the church is taking. The new priest also legitimises violence against all those who think differently. In turn in Holland's ecological and feminist perspective, a clergyman is an epitome of the conservative tradition, which endows men with the ultimate power over all weaker beings. In Pokot the church plays an especially harmful role as it ritualises and sanctions violence. ${ }^{19}$

Such films feature priests as representatives of the old order, trying to preserve a status quo which basically benefits them, their social status and position, and the accumulation of material goods. Within their community they occupy a position intended for a role model, but it is not due to the worthiness of the priests and the values they profess, or religion itself, but rather to the inertia of old customs, social norms considered inviolable and the interaction of participants in the local system of power. It is worth mentioning in this context Smarzowski's Wesele (Wedding, 2004), where the priest, in a major if not fully formal role in the community, corrupt and focused on mundane matters, and an alcohol lover, is a perfect match for the local society. Smarzowski, placing the priest in his signature exaggerated world and in the meticulously depicted (and not only provincial) Polish mentality, in a way treats this figure as among those foreshadowing the protagonists of Clergy.

\section{3.}

Like Clergy, other films by Wojciech Smarzowski, arguably one of the major Polish directors of the past two decades, have caused quite a stir among their audiences. His movies, enticing the viewer with exaggerated form, uniquely grotesque, and not infrequently filled with violence and atrocities, are at the same time attempts to come to terms with both Polish history and the present. Andrzej Szpulak observes:

The public [...], especially its young part, embraced Smarzowski's movies as [...] the turning of the world upside down on screen, as entry behind its simulated face, as getting in depth of the evil that informs it. ${ }^{20}$

The protagonists of Smarzowski's films are full of

cunning and thievery, weakness and ruthless conformism, lack of principles and hypocrisy, unbridled greed and brutal violence, and finally omnipresent drunkenness, vulgarity and viciousness. $^{21}$

\footnotetext{
19 Ibidem, p. 34.

20 A. Szpulak, Róża, Poznań 2016, p. 19.

${ }^{21}$ Ibidem, p. 18.
} 
Human relationships are a sham, and while this world is not completely bereft of values, they often have no chance of coming to light. Smarzowski exposes hypocrisy and duplicity, the true face of Polish reality. His critics note that naturalism obscures the truth, and the director is "unable to come up with any positive project, with anything that would be a worthwhile alternative to the despised reality." 22 The question arises, however, as to whether this is actually the task of cinema. Smarzowski certainly has no intention of offering the viewer some kind of therapy, and he does not do so in Clergy, either.

Although his films reveal the darkest sides of reality, goodness is traceable in them, even if the ruthlessness of the world and human weaknesses destroy and subdue it. Paulina Gorlewska points out the contempt in Smarzowski's work: "individuals and whole communities, villagers, policemen, corrupt provincial officials, alcoholics, Soviets and Russians, Ukrainians, and the clergy are repulsive." ${ }^{23}$ Tadeusz Sobolewski counters this observation, pointing to tragic and innocent characters such as Fr. Kukuła in Clergy. ${ }^{24}$ Sobolewski adds that evil is too widespread today and indifference to it can be overcome only through horror, which also results from the convention of Smarzowski's films. One can instead speak of the helplessness and failure of the protagonists, a characteristic feature of his films.

In Clergy, Smarzowski crosses a line beyond which Polish cinema had never before ventured. The film is an amalgamation of evil: corruption, greed, manipulation, cruelty, heartlessness, pride, anger, and gluttony. One could say that the seven deadly sins are just a starting point for Smarzowski to build upon. Pedophilia is the gravest offence committed by priests. While ruthless coercion or financial embezzlement may arouse anger, they are in a sense considered socially pardonable. No such justification can be found for pedophilia. Here Smarzowski shatters a taboo, in both the content and the form. In no other film has the triumph of the church been contrasted so unmistakably with the silent suffering of people hurt by that institution (the brilliant editing in particular, among other elements, helps to achieve this impact). Moreover, if the problems of priests had been touched upon before, they were presented as human errors, as individual foibles, and never as an inherent feature of a certain social structure. Even when cinema focused on the institutional dimension of the Catholic Church, it very rarely focused on the church itself as an institution that perpetrates and protects evil.

Clergy is moreover responsible for one more major shift with respect to earlier images of the priest. In previous films, the priest, whose actions and attitudes were highly respected, was portrayed as representing the entire church. This was especially evident in historical films. However, when he had to face his own weaknesses and problems, he was shown as an individual who belonged to the church yet did not personify it. Wojciech Smarzowski has turned each of his characters into a countenance of the church. He does not refer to individual priests as much as to the entire clerical state and the church as an institution, as the title itself implies.

\footnotetext{
22 See P. Gorlewska, Polityka wstrętu, moralność obrzydzenia, "Kino" 2018, no. 10, p. 55.

${ }^{23}$ Ibidem.

${ }^{24}$ T. Sobolewski, Rekolekcje ze Smarzowskim, "Kino" 2018, no. 11, p. 98.
} 
Three priests are the protagonists of Smarzowski's Clergy: Andrzej Kukuła (Arkadiusz Jakubik), Tadeusz Trybus (Robert Więckiewicz), and Leszek Lisowski (Jacek Braciak). Once rescued from a fire, they meet yearly on the anniversary of that event, even if in principle the ties between them are not very strong. Their dramaturgical relations are weak, as well. Smarzowski's aim is to present people who differ in terms of ethics and material wealth but in fact represent a very similar image of a priest. The environment in which the priest operates is irrelevant. The way a priest functions in the provinces, so important in Przemysław Wojcieszek's films and plays ${ }^{25}$ and various popular series, ceases to matter in Smarzowski's film. The protagonists differ in their positions in the ecclesiastical hierarchy: Lisowski works in the curia and aspires to the Vatican, whereas the other two are parish priests: Kukuła in a medium-sized city and Trybus in a poor rural parish. The differences between an episcopal curia, a rich parish and a poor parish are merely those of scale and do not arise from the way the individual characters behave and their relations with their immediate environment.

The priests in movies are a priori ascribed the highest moral stature, which becomes a point of reference for the transformation of the character or for revealing the imperfections in the original image. These imperfections usually do not destroy the positive impression, but only complete the character, making him more "human." Smarzowski does things differently. From the very beginning he shows that the priest's everyday life does not consist of praying and helping the needy, but of hangovers, swindling money from the faithful, and total subordination to his superiors, who have no respect for him whatsoever.

A priest's everyday life arouses curiosity because it is halfway between the sacred and the profane. Smarzowski depicts this life and strips it of mystery, revealing in fact that there is nothing sacred here. Under the guise of sanctification, a hold-over of tradition and the social importance ascribed to it, there is only the commonplace, which, as in all of Smarzowski's films, is fraught with pathology. A priest is required, as are other people in the public trust, to keep his private life in line with officially professed principles and values. Smarzowski shows a stark discrepancy between the official image of the priest and his everyday conduct.

In most films, the church is a dignified and safe space, a haven to those in need. In Clergy, the higher the priest's position, the more degraded the space around him. Whenever archbishops or cardinals were depicted in previous Polish films, they tended to be historical heroes or figures who admonish their flock in a paternal manner. Smarzowski adds a fourth character to his three protagonists. While Kukuła, Trybus and Lisowski are multidimensional, Archbishop Mordowicz (Janusz Gajos), with his telling name (derived from morda- mug), is a far-fetched figure, although the audience could easily identify his similarity to a few Polish church leaders. ${ }^{26}$ The purpose of this character is to expose the hypocrisy, cunning, contempt for others and

${ }^{25}$ It is about movies like Gtośniej od bomb (Louder Than Bombs, 2001) and Made in Poland (2010) and plays like Osobisty Jezus (Personal Jesus, 2006) and Ja jestem zmartwychwstaniem (I Am the Resurrection, 2007).

${ }^{26}$ See e.g. A. Pawlicka, Ruina. Sprawa abp. Głódzia, "Newsweek" 2019, no. 46, p. 16. 
callousness of the high officials of the institution, as well as to demonstrate the total subordination of the state authorities to the whims of individual ecclesiastical leaders.

In films and TV series set in the present, priests who are able to influence politics are shown with subtle irony or even distaste, which is yet combined with a kind of admiration for their "diplomatic" talents. In concluding his paper about the priest in Polish movies, Robert Birkholc calls for films depicting

the complicated relationship between the church and the state, the phantasmagorical position of priests in Polish consciousness, or the nationalistic inclinations of some clergymen. ${ }^{27}$

This was missing from other films; Clergy seemingly does it. One scene shows a character resembling the former priest Fr. Jacek Międlar, infamous for his nationalist and anti-Semitic statements and actions, who takes pastoral care of a nationalist fascist phalanx. Smarzowski points to the unequal relations between the church and politicians, to the total subordination of state authorities to the decisions and whims of individual church leaders, who treat politicians as instruments to further their power and pride. However, it is difficult to describe the relations between the church and the authorities as complex; the picture is completely unambiguous and unfavourable for both sides.

The second motif concerning the relations between the church and politics was the struggle of priests against the communist system. Their moral superiority was unquestionable, with the good they represent pitted against the evil personified by party functionaries and the Security Service. Clergy clearly counters all those historical and hagiographic narratives. We see here a reversal of certain topoi. The role of the church in history is represented by and embodied in, the suffering of a young boy. As a child, Fr. Kukuła was repeatedly raped by a priest who celebrated Mass for the homeland and instilled courage and hope in the Polish people as they struggled against the communist regime. ${ }^{28}$ Smarzowski observes that no degree of personal merit towards religion, the state or the nation can justify a life of iniquity or offset the evil inflicted on people. At the same time he is critical of the links between patriotism and religion in Polish culture and consciousness. No other film had addressed this issue before.

Clergy, just like $W$ imię..., addresses the problem of the carnal desires and sex lives of priests. Smarzowski, however, applies a completely different emphasis. The priest's infatuation with a young boy in Szumowska's film is one thing; Smarzowski's explicit reference to paedophilia in the Church, to behaviour that is socially, morally, and legally unacceptable, is an entirely different matter. Smarzowski, importantly, links it to the attitude of the church as an institution directly responsible for the evil done. Focusing on priests, he takes into account the perspective of the victims they have wronged. However, it must be stressed that priests are also among the victims.

${ }^{27}$ R. Birkholc, op. cit., p. 35.

${ }_{28}$ The scriptwriters did not invent this story. A few months after the premiere of Clergy, the late Father Henryk Jankowski, a chaplain of Solidarity and a close friend of many influential politicians who were eager to emphasize his historical and political merits, was accused of many years of sexual abuse of minors. 
Fr. Kukuła was a victim of a paedophile priest as a child. It is worth noting, however, that although Smarzowski invites such an interpretation, he is more concerned with exposing the culpability of the church than portraying the situation of the characters. While the filmmakers do not make it clear who is responsible for abusing the little boy, Kukuła or Lisowski, there is no doubt that it was a clergyman.

Smarzowski does not deny priests' their sexuality, but points out its entanglement in the way the institution functions. Fr. Trybus's sexuality and his sexual relations with a steady partner (Joanna Kulig), is made highly emotive by the carnality displayed in the nudity of both characters, and, more importantly, by making this intimate relationship commonplace. Szumowska was first to address a priest's sexuality and carnality, yet of utmost importance in her movie was the dilemma of the protagonist's sexual orientation. What arouses the most intense emotions in Smarzowski is not so much the priest's sexual affair with his housekeeper Hanka (although it would be more appropriate to say that his household is taken care of by his partner), but its obviousness. The director does not criticize the intimate relationship of this couple, but rather the hypocrisy surrounding the priest who conceals this fact, in accordance with the tradition and norms of the Church. Here the church is once more the accused, adhering to rules that do not respect human biological and psychological needs.

Robert Birkholc moreover notices that "stories about priests are most often hisstories, where women mainly play the roles of saints or whores, priests' silent assistants or sinful temptresses. ${ }^{.29}$ In this context one should take note of Hanka, who does not seem to fit into any of the above categories. She cohabits with the priest, becomes pregnant with his child, and is his protector and confidante. Her integrity and caring enable Trybus to come to terms with himself. It is impossible not to get the impression, however, that Hanka's character is secondary in itself; she is significant primarily in what she reveals about Trybus. The woman comes close to having an abortion, which the man initially persuades her to do and later dissuades her from doing. This situation becomes his test of humanity, one which he manages to pass.

Therefore, Trybus is the only one of the three protagonists who wins, although more as a good man, not as a good priest. He is saved by his love for a woman and the awareness that they will have a child. In a sense he resembles the priest from Historie milosne in this respect, although Smarzowski, unlike Jerzy Stuhr who spoke of expressing love for God through love for another human being, shies away from but a trace of Christian reflection in this character.

Polish cinema presented the image of a priest, as Anita Piotrowska writes in her review of $W$ imie ..., "torn between obedience to the institution, his faith and purely human desires. ${ }^{.30}$ Clergy nearly fits the stereotype; nearly, as there is no relation here between the priest and the faith. Moreover, in Smarzowski's work this rift between the rules of life within an institution and human desires is not, despite appearances, a drama of equivalent attitudes or values. His authorial commentary leaves no doubt about it, and a censure of the institution dominates.

\footnotetext{
${ }^{29}$ R. Birkholc, op. cit., p. 32.

${ }^{30}$ A. Piotrowska, Fantazja o fajnym księdzu..., op. cit., p. 40.
} 
Smarzowski has declared straightforwardly: "From the very beginning we wanted to make a film about a corporation, an institution, not about faith. Faith is an intimate matter." ${ }^{31}$ In fact, however, in the world of Clergy faith does not really exist. Priests do not undergo existential dilemmas and do not struggle with their faith. This theme is barely noticeable. Lisowski is judged through the prism of his career and pedophilia and Trybus through the life of a village parish priest, more focused on alcohol, the woman he has feelings for, and making money for his daily life. Perhaps in Kukula's case the problem of faith is more pronounced, but it is also just a secondary motif, in a way complementary to his portrait, but certainly not its main component. Smarzowski does more than just divorce the institutional church from the sacred; in his world, the sacred is simply absent. Hence the ironic paraphrase of The Last Supper, used similarly to expose religious hypocrisy as did, for example, Luis Buñuel in Viridiana (1961) and, in Polish cinema, the authors of Stacja Warszawa (Warsaw Station, 2013).

Therefore, perhaps somewhat paradoxically, the characters in Clergy are not all that far removed from other portrayals of priests. Their dilemmas and crises are not theological in nature. The aforementioned words of Fr. Adam Boniecki, that most films do not really consider priests as priests, but as people in extreme situations, ${ }^{32}$ can in a way refer to Clergy. The uniqueness of the characters in Smarzowski's film lies, of course, in their membership in the clerical state, but not in the context of their faith, their specific relationship with God or the resulting direct relationships with the faithful, with other people. It is more about social responsibility and the discord between the officially proclaimed system of values and its implementation.

\section{4.}

Three films shot after Clergy and featuring the image of a Catholic priest deserve special attention. Tylko nie mów nikomu (Tell No One, 2019) and Zabawa w chowanego (Hide-and-Seek, 2020) by Tomasz Sekielski, are shocking documentaries which in some sense not only supplement one of the principal motifs in Smarzowski's movie but go much further. Confronting perpetrators and victims, they tell the story of pedophilia in the Catholic Church. They accuse specific priests of sexual crimes and the Catholic Church of covering up these crimes and of conspiracy against the victims.

In Clergy a genuine priest is a false authority, while in Boże Ciało (Corpus Christi, 2019) by Jan Komasa, nominated for the Academy Award for Best International Feature Film, a false priest becomes a genuine authority. The protagonist is in a juvenile correctional facility. Fascinated by a priest working with inmates and himself feeling the vocation, he also wants to become a priest. However, he finds out that as a person with a criminal record, he has no chance of following the call. He is sent to work in one of the institutions, but instead of reporting there, he claims to be a priest.

${ }^{31} \mathrm{http} / / /$ weekend.gazeta.pl/weekend/1,152121,23984346,kler-wojciech-smarzowski-kosciolpotrzebuje-politykow-bo.html [access: 5 November 2019].

${ }^{32}$ Fr. A. Boniecki, Sami, ale nie samotni..., op. cit., p. 18. 
As the result of a coincidence, he is asked to fill in for the local parish priest. Suddenly, the fake priest starts doing real good. He gets to the source of the local community's trauma. He becomes important to the faithful, although from a theological point of view one can question the validity of the rituals he performs. He does not cease to be just a youth pretending to be a priest. The complications that arise open up numerous possibilities for interpretation.

Over the past year Boże Ciało has become the Polish movie to provoke most urgent questions and reveal something important about Polish society, including the Catholic Church. Jan Komasa, referring to Clergy as among those films that provoke conversations and have a potent impact, indicated that until then Polish cinema had not dealt with the church as an institution. The power of Boże Ciało lies in posing questions about the meaning of priestly service, about who the priest should be for the faithful, about the meaning of vocation (i.e. who can become a priest), about - as he himself asks - "Must one be a priest to help others in spiritual terms? Where does one seek meaning outside the Church?"33 The movie differs from Clergy not only in terms of the questions posed but also as to the ways in which they are asked. According to Anita Piotrowska, referring among others to Smarzowski's oeuvre, “Komasa's perception is marked by no sense of superiority, neither as to form, nor scathing satire, nor moral reproof." ${ }^{34}$ It is possible that Boże Ciało has ushered in a new chapter in the history of the portraits of Catholic clergy in Polish cinema.

Translated by Marcin Turski.

\section{References}

Birkholc R., Duszpasterze, kapłani i klechy... Księża w polskim filmie fabularnym, "Magazyn Filmowy" 2018, no. 10, pp. 28-35.

Boniecki A. Fr., Sami, ale nie samotni, “Tygodnik Powszechny” 2006, no. 39, p. 18.

Draguła A. Fr., Księża prowincjonalni. Obraz kapłana $w$ twórczości teatralnej i filmowej Przemysława Wojcieszka, "Notatnik Teatralny" 2008, no. 48, pp. 141-146.

Garbicz A., Lis M. Fr., Filmowe portrety pontyfikatu. Jan Pawet II w 100 odstonach, Katowice 2007.

Gorlewska P., Polityka wstrętu, moralność obrzydzenia, "Kino” 2018, no. 10, pp. 52-55.

http://weekend.gazeta.pl/weekend/1,152121,23984346,kler-wojciech-smarzowski-kosciolpotrzebuje-politykow-bo.html [access: 5 November 2019].

KK [K. Kornacki], Religii przedstawienie w kinie polskim, [in:] Światowa encyklopedia filmu religijnego, Fr. M. Lis, A. Garbicz (eds.), Kraków 2007, pp. 459-460.

Lis M. Fr., Filmowe portrety Karola Wojtyty. Rekonesans, [in:] Filmowa biografistyka. Ekranowe interpretacje losów i faktów, T. Szczepański, S. Kołos (eds.), Toruń 2007, pp. 67-88.

Luter A. Fr., Ksiądz w polskim filmie, [in:] Ukryta religijność kina, Fr. M. Lis (ed.), Opole 2002, pp. 37-49.

Łaciak B., Kwestie społeczne w polskich serialach obyczajowych-prezentacje i odbiór, Warszawa 2013.

${ }^{33}$ Przywracanie do stada, an interview with Jan Komasa by Janusz Wróblewski, "Polityka" 2019, no. 41 , p. 92.

${ }^{34}$ A. Piotrowska, Księżowski freestyle, "Tygodnik Powszechny” 2019, no. 41, p. 94. 
Mazur D., Prymat doświadczenia religijnego nad instytucjonalnością. Obraz duchowieństwa w filmach "Faustyna" Jerzego Eukaszewicza $i$ "Prymas. Trzy lata z tysiaca" Teresy Kotlarczyk, [in:] Kino polskie po roku 1989, P. Zwierzchowski, D. Mazur (eds.), Bydgoszcz 2007, pp. 37-47.

Pawlicka A., Ruina. Sprawa abp. Głódzia, "Newsweek” 2019, no. 46, pp. 12-16.

Piotrowska A., Fantazja of fajnym księdzu, "Tygodnik Powszechny" 2013, no. 37, p. 40.

Piotrowska A., Księżowski freestyle, "Tygodnik Powszechny" 2019, no. 41, pp. 94-95.

Podsiadło M., Wiek klęski. Kino Wojciecha Smarzowskiego, "Ekrany” 2016, no. 6, pp. 51-54.

Ponikło T., Kuszace sutanny. Wizerunek księdza w serialach, "Tygodnik Powszechny" 2008, no. 45 , p. 18.

Przywracanie do stada, an interview with Jan Komasa by Janusz Wróblewski, "Polityka" 2019, no. 41 , p. 92.

Sobolewski T., Rekolekcje ze Smarzowskim, "Kino" 2018, no. 11, p. 98.

Szpulak A., Róża, Poznań 2016. 